\title{
Strengthening the Concept of Preventive Theory (Sadd aż-Żarīah) Against Adolescent Reproductive Health
}

\author{
$1^{\text {st }}$ Heni Nurhaeni $1,2^{\text {nd }}$ JM. Muslimin $2,3^{\text {rd }}$ Ani Nuraeni ${ }^{3}, 4^{\text {th }}$ Elina Lukman ${ }^{4}, 5^{\text {th }}$ Gustop \\ Amitiria $^{5}, 6^{\text {th }}$ Arif Sumantri ${ }^{6}$ \\ \{hnurhaeni@gmail.com¹, jm.muslimin@uinjkt.ac.id ${ }^{2}$, aninuraeni49@y ahoo.co.id ${ }^{3}$, \\ elina_lukman19@mhs.uinjkt.ac.id ${ }^{4}$, gustop.amtiria@poltekkes-tjk.ac.id ${ }^{5}$, arif.sumantri@uinjkt.ac.id $\left.{ }^{6}\right\}$ \\ Health Polytechnic of Tanjung Karang, Lampung, Indonesia ${ }^{135}$, Sy arif Hiday atullah State Islamic \\ University of Jakarta, Indonesia ${ }^{246}$
}

\begin{abstract}
A point of view in understanding the problem of the risk of damage and the difference in the use of the istinbat method can be done with the istinbat law method of Sadd aż-żarīah which considers mafsadat and maşlahat. Sadd aż-żarīah is a prohibition against anything that was originally permissible so that it does not lead to what is forbidden. The same goes for education about reproductive health that is delivered by families/teachers/peers to adolescents. Reproductive health is a series of conditions for the development of adolescents, which have been misinterpreted and even taboo for discussion. Therefore, through mix-method research, with 188 respondents online, studies, discussions, and reinforcement were given to evaluation for 3 months. Strengthening the preventive theory (Sadd aż-żarīaht) was carried out in this study to avoid self-damage to the susceptibility of adolescents, even to imparting knowledge of sex education which resulted in early pregnancy / venereal disease. The results showed that physical growth and damage due to promiscuity affect the intervention of assertive acceptance and reproductive growth and development in adolescents.
\end{abstract}

Keywords: Sadd aż-żarīah, Reproductive Health, Adolescent Growth.

\section{Introduction}

Sadd aż-żarỉah[1] in Munawwaroh[2] is composed of two lafadz (iḍofah), namely w which has the meaning of closing the blemish, closing the damage and preventing or it can also be interpreted as the opposite of the word to open.[3] While lafadz اذلريعة means, wasilah, and way.[3]

Sadd aż-żarỉah according to Ibn Asyur is a term (laqab) used by fiqh experts regarding the method approach to canceling, preventing even prohibiting actions (not containing elements of damage) which are thought to lead to damage. Al-Mazri also explains the same thing that sadd aż-żarīah is a prohibition against everything that was originally permis sible so that it does not lead to things that are prohibited. [4] The main cause of this method of prevention is the purpose of carrying out a job that leads to prohibition or damage.

[5]Likewise with the life journey of a teenager. A teenager has physiological changes that require reinforcement both from himself and from those in his environment. This condition is considered important because adolescent reproductive health will affect the physical and psychosocial health status of adolescents in the future. 
[6] Carver,[7] and Samlee Plianbangchang [6] state that adolescence (ages 10-19 years) is a period of a rapid transition in life from "childhood" to "adulthood". This phase of life is full of opportunities and healthy youth is a great as set to contribute to national development. But at the same time, adolescents are also faced with risks and vulnerabilities. Lussier \& Fitzpatrick (2016) in the WHO Southeast Asia (SEA) region there are around 3

50 million adolescents, which constitute $22 \%$ of the total population. Adolescence is generally considered a healthy period of life because the mortality rate in this age group is relatively low. This condition causes adolescents to face many challenges in their lives and some of them are related to their health. Of course, these health challenges will be different from what they faced when they were younger or older.

Referring to the description above, the researcher considers it necessary to pay attention integrated preparatory intervention for adolescents, especially through strengthening Sadd ażżariah's preventive theory to anticipate deteriorating mental health conditions for adolescents in facing their growth and development environment, both in the family, peer, and social environment even through social media.

The problem of adolescent vulnerability to adolescent reproductive health growth and development conditions is complex. And the purpose of this study is that adolescents can adapt to internal psychological physical changes and anticipate acceptance in their environment. adolescence (ages 10-19 years) is a period of a rapid transition in life from "childhood" to "adulthood." This phase of life is full of opportunities and healthy youth is a great asset to contribute to national development. However, adolescents are also faced with risk and vulnerability at the same time. Lussier \& Fitzpatrick[7] in the WHO Southeast Asia (SEA) region there are around 350 million adolescents, which constitute $22 \%$ of the total population. Adolescence is generally considered a healthy period of life because the mortality rate in this age group is relatively low. This condition causes adolescents to face many challenges in their lives and some of them are related to their health. Of course, these health challenges will be different from what they faced when they were younger or older.

Referring to the description above, it is necessary to pay attention to the in tegrated preparation of strengthening Sadd aż-żarīah preventive theory to anticipate the deterioration of the mental health conditions of adolescents in the face of their growth and development environment both in the family, peer, and social environment. through social media.

The problem of adolescent vulnerability to adolescent reproductive health growth and development conditions. Adolescents must be able to adapt to their internal physicalpsychological changes and anticipate their acceptance in their environment.

Research using a mixed-methods approach, which was conducted for 5 months in 2020, quantitatively and qualitatively and descriptively analytical and equipped with literature study. 188 respondents were randomly taken through social media (Whats App group application) representing all regional provinces in Indonesia during the pandemic period. Data obtained through online and google forms, carried out since identification, building trust in adolescents, intervention using Sadd aż-żarīah prevention theory, ending with an evaluation of youth readiness. 


\section{Results and Discussion:}

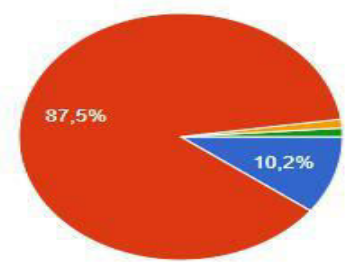

Fig. 1. Distribution of Respondents

Of the 188 respondents who participated in this research activity, there was 102 adolescent (87.5\%), 34 parents (10.2\%), 26 teachers, and 26 friends/neighbours. As for the role of parents, there are 26 people $(25.5 \%)$ as the head of the family, $30.7 \%$ as the eldest child, $34.1 \%$ as the youngest child.

The Role That Adolescents Want

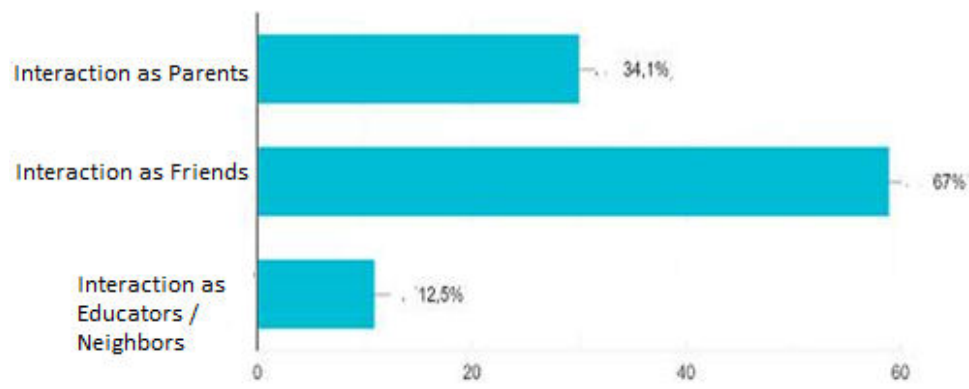

Fig. 2. Architecture of a ty pical wireless sensor node.

Table 1. When Adolescent and Parents chat

\begin{tabular}{|c|c|c|c|}
\hline \multirow{2}{*}{ NO. } & \multirow{2}{*}{ Variable } & \multicolumn{2}{|c|}{ Time } \\
\cline { 3 - 4 } & & Amount & $\%$ \\
\hline 1 & $<1 \mathrm{hrs}$. & 30 & 55,6 \\
\hline 2 & $1 \mathrm{hrs}$. & 26 & 22,2 \\
\hline 3 & $>1 \mathrm{hrs}$. & 26 & 22,2 \\
\hline
\end{tabular}

This condition according to Puchalski[7] and Kuziemsky[7] illustrates that when communicating with adolescents, the process that occurs should be during interaction and chatting or assessing adolescents in a non-judgmental manner, Adolescent who is invited to communicate must be respected and their families/peers also shouldn't judge. We have to assume that adolescents value and believe the same as group beliefs during the communication process in interactions. So that the communication process in interactions with adolescents will be effective if it is carried out for a longer period in an atmosphere of harmony, and is not done hastily. 
Table 2. Characteristics of Interaction Activities on Reproduction between Adolescents and Parents, Peers, and Teachers

\begin{tabular}{lllllll}
\hline Variable & \multicolumn{3}{c}{ Adolescents } & & T & P value \\
& \cline { 2 - 4 } & Mean & SD & $95 \%$ CI & & \\
nyynnnnnn Parents & 1.139 & 0.741 & $-0.414-0.321$ & 0.255 & 0.199 \\
\hline Peers & 0.023 & 1.318 & $-0.019-0.137$ & 0.116 & 0.071 \\
& & & & & \\
\hline Teachers & 0.279 & 1.102 & $-0.19-12.196$ & & 1.969 & 0.056 \\
\hline
\end{tabular}

From table 2. above, it can be seen that the interaction activity between adolescents and parents, peers, and teachers has almost an effect, there is a high difference between parents and adolescents, but it is quite influencing the interaction. However, teachers have a higher influence than peers and parents, namely 0.056 .

Jaruseviciene[7] and Ramirez-garcia[9] explain that information about sexual initiation in adolescents and adolescents is difficult to obtain.

[10]However, the age of sexual debut has reportedly decreased throughout the year in countries in the region. Early sexual activity is as sociated with lower levels of exposure to condom use in adolescents with a risk of sexually transmitted diseases (STIs), HIV infection, unwanted pregnancy, unsafe abortion and its consequences. The need for unmet contraceptive services is high among adolescents in Bangladesh, India and Nepal. The use of available contraceptives is still low in several countries; $87 \%$ of women aged 15-19 in India and 58\% in Bangladesh do not use any contraceptive method.

Table 3. The effect of respondent characteristics on the implementation of preventive interventions Sadd aż-żarı̄ah in the use of film media about adolescent reproduction

\begin{tabular}{llcccc}
\hline \multicolumn{1}{c}{$\begin{array}{c}\text { Variable } \\
\text { Independent }\end{array}$} & \multicolumn{1}{c}{$\begin{array}{c}\text { Variable } \\
\text { Dependent }\end{array}$} & Mean Square & Df & F & P value \\
\hline Physical Growth & - Assertive Acceptance & 1.048 & 1 & 2.062 & $\mathbf{0 . 0 5 7}$ \\
& $-\begin{array}{l}\text { Reproductive } \\
\text { Growth }\end{array}$ & 248.32 & 1 & 0.694 & $\mathbf{0 . 8 3 9}$ \\
& & & & \\
Damage due to & - Assertive Acceptance & 2.441 & 1 & 4.804 & $\mathbf{0 . 0 0 6}$ \\
Promiscuity & $\begin{array}{l}\text { Reproductive } \\
\text { Growth }\end{array}$ & 97.746 & 1 & 0.273 & $\mathbf{0 . 9 4 1}$ \\
& & & & \\
\hline
\end{tabular}

Based on the results of the multivariate test, it was found that physical growth and damage due to adolescent promiscuity affected the intervention, acceptance of as sertive adolescents on reproductive development in adolescents.

This condition was conveyed by 34 informants with similar remarks:

"As parents try to understand the feelings of children, then surrender to Allah Swt."

"Worried"

"a little worried"

"Videos are very useful" 
"You have to be more careful and alert, don't panic and just stay at home"

"You have to be more careful and alert, don't panic and just stay at home"

"I take the positive lesson; I can interact more often with teenagers"

"I even prefer to be at home because I spend more time with my family"

When asked about information about changes in adolescent reproductive health, there were significant differences, found that $60.56 \%$ were;

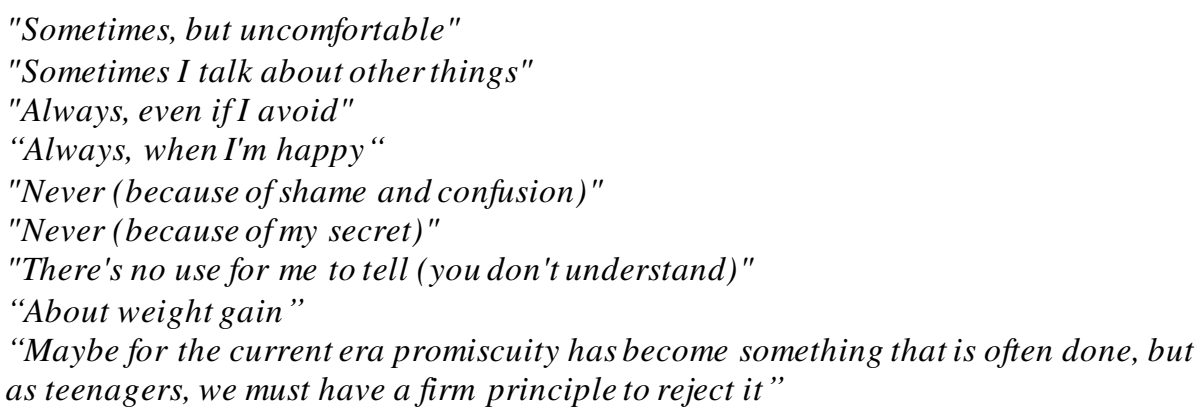

[10]Kessler RC, Angermeyer M, Anthony JC, Berg[11] states that adolescence is an important period in developing and maintaining social and emotional habits that are important for mental health. These conditions include adopting a healthy sleep pattern; do regular exercise; develop coping, problem-solving, and interpersonal skills, including learning to manage emotions. The environment contributes to supporting such as family, schools, and the surrounding community.

It is estimated that $10-20 \%$ of adolescents globally have problems with mental health conditions, but these conditions are poorly detected and treated.

The more risk factors adolescents face, the greater the potential impact on their mental health. Factors that can contribute to stress during adolescence include a desire for more autonomy, the pressure to conform with peers, exploration of sexual identities, and increased access to and use of technology. The influence of media and gender norms can exacerbate disparities between the realities of life of adolescents and their perceptions or aspirations for the future. Other important determinants include the quality of domestic life and relationships with peers.

Some youth are at greater risk of mental health conditions because of living conditions, stigma, discrimination or exclusion, or lack of access to quality support and services. These conditions include adolescents who live in humanitarian and vulnerable environments; adolescents with chronic illnesses, pregnant adolescents, parents of adolescents, or those who are married young and/or forced; orphan; and adolescents from ethnic minorities or sexual backgrounds or other discriminated groups.

Likewise explained by Namazi and Tanatabaie[12] said sex education for children and adolescents is widely considered by Muslims as 'dangerous knowledge for the vulnerable' that 'awakens' premature sexuality (i.e. premarital) and damages Islamic identity. . Such understanding is rooted in part in the general (wrong) interpretation of Islam's emphasis on the 'lack of capacity' of children and their 'need for protection', as well as in the invisibility of youth and agency sexuality in most Islamic traditions. The increasing overlap between 
'immaturity' and 'sexuality' in the lives of contemporary youth has made childhood/adolescent sexuality and sex education a challenging issue for many Muslims today. This demands recognition of childhood/adolescent sexuality and agency as important subjects of examination, particularly in Islamic studies and regarding the sexual education needs of Muslim adolescents.

Individuals experience different sensitivity to the impacts of climate change on different ages and stages of growth in life, especially this occurs in adolescence. For example, the very young and the very old are very sensitive to climate-related health impacts including the process of interacting with peers.[13] Ibnul Qayyim in I'lamul Muwaqqi'in mentions ninety nine content of Saddu Dzari'ah from the Qur'an and As -Sunnah. Dzari'ah from the perspective of being obliged to be closed or prevented is divided into three parts in the opinion of the scholars, namely (1) What is agreed by the people about the obligation to be closed or prevented. (2) What has been agreed by the scholars regarding the obligation to be closed Like prohibiting growing grapes because it will be made into an intoxicating drink? (3) What happened to him was the difference of opinion among the scholars. That is to be cautious about what can be done, but most of it can lead to something that is forbidden. Thus it can be accepted that through strengthening Preventive (Sadd aż-Żarīah) Adolescent Reproductive Health needs to be implemented and developed following the phase of adolescent growth and development.

Rizki Ariani[12] said the principle of ushul fiqih or fiqh method, namely A such as Żarī "ah, which has two meanings namely Sadd aż-Żarræ ah and Fath adz-Dzari'ah. If something comes to better then it is called Fath adz-Dzari'ah, that is, it is permissible, if something/media brings badness then it is called Sadd Dzaria'ah, which is haram like the use of condoms on teenage couples who behave in free sex and especially in interaction behavior as sociation that results in the health of other teenagers. The essence of the dzari'ah rule is that which connects something maslahat to mafsadat. That is if a teenager performs an activity/behavior which is permissible because it contains a benefit, but the goal he will achieve ends in an immunity, just as teenagers can mix with the opposite sex even though they are not mahroms, but when they are sold condoms it will open up opportunities to do so. adultery, because tools/drugs to prevent pregnancy due to intercourse can be found easily in drug stores or pharmacies nearby, this becomes haram.[13]

The vulnerability of adolescents needs to be facilitated and anticipated by the people in their environment, although the health element in a society tends to be only curative (treatment). This condition can protect him from several cases which are maslahat for humans and the desirability of sharia and everything that harms it is categorized as mudhorot and mafsadah which must be removed as much as possible but through the application of the concept of Preventive (Sadd aż-Żarỉah) it can be started with a level of prevention and even towards promotion., so that adolescents as family members can adapt to health y behavior and remain active in their lives according to the teachings of Allah Swt. Hidayah 


\section{References}

[1] S. bin M. sultan Al-'Anzi, Sad adz-Dzara'I 'Inda Imam Ibnu al-Qayyim al-Jauziyyah wa Atsāratuhu fi Ikhtiyāratihi al-Fiqhiyyah. Oman: Dar al-Atsariy yah, 2007.

[2] H. Munawwaroh, "Sadd Al- Dzari'At Dan Aplikasinya Pada Permasalahan Fiqih Kontemporer," Ijtihad J. Huk. dan Ekon. Islam, vol. 12, no. 1, p. 63, 2018.

[3] L. Ma'luf, al-Munjid. Beirut: Dar al-Masyriq, 1989.

[4] M. T. bin Asyur, Maqāshid asy-Syari'ah al-Islāmiyyah. Malay sia: Dār Al-Nafāis, 2001.

[5] A. 'Abdullāh M. bin A. B. Az-Zur'I, I'lām al-Muwaqqi'īn 'an Rabb al- 'Ālamīn. Beirut: Dār al-Jīl, 1973.

[6] S. Plianbangchang, "Promoting Adolescent Health and Development in South-East Asia," Indian J Community Med, vol. 36, no. 4, 2011.

[7] A. Carver, A. Timperio, and D. Crawford, "Playing it safe: The influence of neighbourhood safety on children's physical activity-A review," Heal. Place, vol. 14, no. 2, 2008.

[8] C. Lussier and C. Fitzpatrick, "Feelings of Safety at School, Socioemotional Functioning, and Classroom Engagement," J. Adolesc. Heal., vol. 58, no. 5, pp. 543-550, 2016.

[9] M. P. Ramirez-garcia, M. Gagnon, S. Colson, J. Côté, J. Flores-aranda, and M. Dupont, "Mind-body practices for people living with HIV : a systematic scoping review," 2019.

[10] K. RC, A. M, and A. JC, "A systematic review: the influence of social media on depression, anxiety and psychological distress in adolescents," IInternational J. Adolesc. Youth, vol. 25, no. 1, 2020.

[11] D. D. Berg and E. Al., "Clinical Practice Patterns in Temporary Mechanical Circulatory Support for Shock in the Critical Care Cardiology Trials Network (CCCTN) Registry," Circ. Hear. Fail., vol. 12, no. 11, 2019.

[12] M. Namazi, "Thematic Approach to Qur'an Exegesis," Messag. Thaqalayn, vol. 10, no. 4, 2010.

[13] Munawwaroh and Hifdhotul, "Sadd Al- Dzari'At Dan Aplikasinya Pada Permasalahan Fiqih Kontemporer," J. Ijtihad, vol. 12, no. 1, 2018.

[14] Rizki Ariani, "Perspektif Mui Kota Palangka Raya,” 2019. 